\title{
IDENTITY, IDENTIFICATION AND DIFFERENTIATION IN CONTEMPORARY BRAZILIAN COMEDIES
}

\section{ANTONIO CARLOS RODRIGUES DE AMORIM}

School of Education, University of Campinas

\section{DAVID MARTIN-JONES}

Film and Television Studies, University of Glasgow, UK

We explore how French philosopher Gilles Deleuze's notion of the 'powers of the false', from Cinema 2, enables a consideration of the ways in which national identity is negotiated in two popular Brazilian comedies of the 2000s, Se Eu Fosse Você/If I Were You (2006) and Se Eu Fosse Você 2/If I Were You 2 (2009). The films offer possibilities for various Brazilian audiences to reimagine national identities "against the grain" of a movement-image blockbuster with an apparently homogenising white, middle class, nuclear family-oriented, normative image of national identity. Studying the aesthetics and narrative of these artistic productions, how they represent the world visually, helps us understand their implications for people. In this way we seek to uncover the potential value of such films for discussions of how cultural identities are constructed, which by turns can contribute to the development of curriculum studies.

Keywords: Cinema. Difference. Powers of false. COMÉDIAS BRASILEIRAS CONTEMPORÂNEAS

Exploramos como a noção de Deleuze da "potência do falso", proposta no seu livro Imagem Tempo, permite levar em consideração e analisar as maneiras pelas quais a identidade nacional é negociada em duas comédias brasileiras populares da década de 2000, Se Eu Fosse Você (2006) e Se Eu Fosse Você 2 (2009). Os filmes oferecem possibilidades para várias audiências brasileiras de reimaginar identidades nacionais contra a corrente de uma padronização de imagem-movimento propagada por cinemas comerciais, estilo "blockbuster", que operam reafirmando uma imagem normativa de identidade nacional, idealmente homogênea, de classe média, nucleada pela família e marcadamente classista. Estudar a estética e a narrativa dessas 
produções artísticas, como elas representam o mundo visualmente, nos ajuda a entender suas implicações e consequências para as pessoas. Desta forma, procuramos discutir o valor potencial de tais filmes para pensar como as identidades culturais são construídas, o que, por sua vez, pode contribuir para o desenvolvimento de estudos curriculares.

Palavras-chave: Cinema. Diferença. Potência do falso.

\section{RESUMEN IDENTIDAD, IDENTIFICACIÓN Y DIFERENCIACIÓN EN COMEDIAS BRASILEÑAS CONTEMPORÁNEAS}

Exploramos como el concepto de "La potencia del falso", de Deleuze, propuesto en su libro Imagen-Tiempo, permite llevar a cabo y analizar como la identidad nacional se negocia en dos comedias brasileñas populares de la década de 2000, Se Eu Fosse Você (2006) E Se Eu Fosse Você 2 (2009). Las peliculas ofrecen posibilidades para distintas audiencias brasileñas de reimaginar identidades nacionales contra la corriente de una padronización de imagen-movimiento propagada por cinemas comerciales, estilo 'blockbuster', que operan reafirmando una imagen normativa, de una identidad nacional, idealmente homogénea, de clase media, de núcleos familiares y de marcadores clasistas. Estudiando laa estética de las dos producciones artísticas, buscando comprender sus implicaciones para las personas y las representaciones de las identidades, a partir de los ensayos de cine en las tecnologías desde la configuración de las miradas y las narrativas, buscando contribuir para las discusiones tan importantes desde el campo de estudios curriculares.

Palabras clave: Cinema. Diferencia. Potencia de lo falso.

\section{An Introduction}

With the philosophical creations of Gilles Deleuze, we can leverage encounters between education and images which can educate beings often skeptical about a possible senseless world: vestige, fragment, ruin and features (WUNDER et al, 2006). By creating planes without depth, there is something one cannot understand and represent in familiar words. The successive deviation of subjective interpretations of that which sees, reports, utilizes, experiences, indicate the negotiation, or the refusal of meaning by bodies. Here, then, is the image; this is what we should pay utmost attention to.

We cannot consider the image as an object, or as an outer space to be described, analyzed, or judged (as we might a city to be defended or a place to invest in, a temple to protect from all impurity). Language makes the image, an object and the eye together, a subject - abstract geometrization, spaces of interiority, clichés. If the image becomes an object, it is better to speak of the language that is imposed on it, and that says, this is my body (PARENTE, 2004, p. 29). 
Amorim's purpose, in his research projects, in considering the relationships between education, film, photography and literature also creates - much as Deleuze's philosophy creates - only with the idea of the surface of language (without the search of essential depths), centered on subjects. I seek to think through this language, focusing / defocusing in the predicate and not in the subject attending to the event, so as to understand how being-things progress meaning. Thinking via the surface of language is an invitation to come by its effect of multiplicity, and its continuous expansion of the senses, outside of the precepts of representational thought.

Studies that interpret the image as representation might typically focus on their producers and consumers: what is behind the images, in the subjects that express and produce representations by language. In view of this, the encounter is what marks the subject and the writing; and the production of images is a discursive mark, a scar.

In other studies (AMORIM, 2007, 2009a and 2009b), pursuing a post-structuralist path, that will understand the story as a constant fiction of present time, Amorim has presented writings produced in teacher training courses, literary images, of film and contemporary photographs. The gamble is a focus on subjects that are not only identifiable by their scars, but also by the gaps that occur in the encounters with beings / things, in the places without dust and without sleep within us (LISPECTOR, 1998). Thus can be produced a possibility of studying writing and images whilst looking for the opening / becoming, and not for the scar / identity.

These preceding analyses of national cinema, as well as of Brazilian photography, by Amorim, raise recurring questions concerning the Brazilian national identity. This is an identity that for many is globalized, unrooted and deformed; marked by violence, disillusion and presentism. It is futureless. Cinema, photography and literature are syntonic, often critically, in varied intensities, aligned with global developments. This is different from theorizations of education and/or of our possibilities of 'understanding reality'. Rather than representing reality, educational theorization creates realities apart from the real. Our notions of fiction, truth and imagination are conceptual forces for another world. To exlore this phenomenon, Amorim is joined in the middle section of this article by Martin-Jones (from the discipline of Film Studies, in the UK), specifically for the exploratory film analysis after Deleuze.

\section{Education, Images and Gilles Deleuze}

The proposal of the research ${ }^{1}$ that this paper is connected to establishes a plan for understanding a geography of sensations and their filmic composition. It undertakes the challenge of thinking without representation. Here, addressing the power of words, images and objects seems to me a political commitment, to be adopted and I do this when I articulate analysis of cinematic images, of literature and of records of curricular productions for schools.

The connections between the image and the field of education (curriculum and scientific and cultural dissemination) wagers on discussions of time, from the conceptualizations from Deleuze's philosophy: the relations between time, being and event; the relationships between time, image and duration of the Deleuze's studies on cinema; the relationships between time, sign and sense of Deleuze's studies on literature.

Maurizio Lazzarato (2007) proposes a work with the definition suggested by 'Bergson and

1 "Intervalar o currículo: potência das audiovisualidades" (Processo CNPq 484908/3-23-8). "Para além da representação - conexões entre educação e estudos de cinema e vídeo experimentais" (Fapesp Proc. N. 2015/256561). 
Deleuze' of time as a continuous creation of unexpected news. Bergson famously proposes that the operation of time be considered via the shape of a cone. A cone in which the time, constricts and dilates toward its tip, and expands toward its base. The present is the tip of the cone, and corresponds to the most contracted degree of duration, that would be the matter, the current one. (SPEGLICH, 2009)

All the rest of this cone is past, a pure virtuality, which is organized in levels:

There is a coexistence of all levels or all degrees of contraction and distension of the past, a virtual repetition of all the past at the same time and at all levels. In addition, at the base of the cone, which would be the more expanded / stretched degree, of length: the memory. Past and present are not within this idea, at successive times, they are coexisting. The duration can be the variation of being alive perpetual present, an alive present that is already past (since the present is present) and at the same time, dragged into the future. From a non-chronological time and non-spatialized, we can think in movements that are non-spatial, but movements of contractions and expansions, expansions and densifications (SPEGLICH, 2009, p. 35).

With this in mind, the effort that we undertake in composing education as a field of sensation (linking sign and perception) and writing, as a field of artistic composition (linking time and the event of producing a plan for thinking with the image for Education, to the idea of difference that Deleuze has proposed to Philosophy) are shown as a power. I (AMORIM, 2009a) consider it original, because it proposes some displacements and deviations of important thoughts to the field. For example, affixed in Education it empties it of the humanist substance that currently saturates it. It helps us to seek alternative ways to survive in a post-human status: as sleepwalker, unconscious, without action, uninhabited (JAGODZINSKI, 2014).
This form of thinking the subject by the 'game' of difference rather than in the orbit of the identical (of the same, of permanence), generates transformations in ways of looking and of producing images as resources for the construction of our everyday experiences and our imaginary. This expression cannot be submitted to analysis and interpretation, but instead can be taken as possible and true in the presentation of everyday life. It is thus possible to steer towards the understanding of image as documents (as evidence, as artifices) so as to bring alive real subjects, concrete situations and aspects of context for a kind of writing that wants to impregnate the everyday.

\section{Paper Purposes and objectives}

Certain contemporary artistic works express (in an exemplary manner) the circumstances of a certain currentness (PINAR, 2011). Analysis of national cinema raises recurring questions concerning Brazilian national identity. This is an identity that for many is globalized, unrooted and deformed; marked by violence, disillusion and presentism. It is futureless. This is different from theorizations of education and/or of our possibilities of 'understanding reality'. Rather than representing reality, educational theorization creates realities apart from the real.

In Brazil on Screen, Lúcia Nagib (2007), one of the most influential scholars currently writing on Brazilian cinema, considers contemporary films in terms of their construction of different kinds of utopian and dystopian images of Brazil. Lisa Shaw and Stephanie Dennison take a somewhat similar approach in Brazilian National Cinema (2007). Yet the phenomenon of an 'interrupted utopia' (p.101) or even a dystopian Brazil that is rendered in such films (as it has been astutely observed by the sophisticated analyses of these scholars), can be said to produce a figuration of the Brazilian people 
as an anomaly of pure forms, as though a "deformation" of what was wished or expected in terms of the constitution of Brazil and Brazilian identity.

When Amorim dealt with the question of dystopia, following Nagib's suggestions, and proposed the concept of curriculum disfiguration (AMORIM, 2011), he aimed to bring this idea to the field of curriculum studies - which in Brazil seems primarily to be interested in the figure of a subject (human, preferentially). Amorim suggested that identification would occur out of the force of the violence of a disfiguration. This is not a matter of pointing out the irony of melancholy or nostalgia, as we find in other types of peripheral cinemas of the world. Rather, dystopia is a category that politically affirms cultural identifications in a field of degradation, of defocussing and 'malformation'.

By contrast, then, certain recent popular Brazilian films, even if aspirational in their depiction of social classes and luxurious lifestyles, do not engage in precisely this type of discourse on Brazil (as either a utopia or dystopia). Rather, they enable us to consider how genre films can produce social analyses that suggest different social typologies, cultural experiences and Brazilian identities. ${ }^{2}$ Hence, in the following analysis we explore how two popular comedies enable a new form of thinking on a plane of immanence which glimpses the future of a national identity yet to come, no matter how comically rendered or mainstream and conservative this is initially ren-

2 As per a post-colonial perspective (Jankie, 2009), we recognize that issues of language construction are closely linked to the notion of representation. There is a similar implication for the field of education, "considering the post-colonial theories critique the process of production of images about the Other and recognize the need of the Other to construct forms of representation that conform to their worldviews, a post-colonial interpretation and understanding of language education policies implies situating them within broader power relations"(p. 246) dered in its ideological expression. We show how these two films, which focus very specifically on a certain social class in Brazil (white, wealthy, middle class, middle aged, suburbanite) in a way that seems to render it normative, can also provide entry points for various audiences in a contemporary Brazilian society, marked by stark contrasts in terms of wealth, ethnic, religious and sexual identities.

The methodology is in part based on Hickey-Moody (2013), amongst others, and considers how cinematic figures invite us to think the “boundaries of 'majoritarian' thought, pushing sensory becomings into the realm of the conceptual of creating experiences in which one is challenged to partake in the action by which the common event itself eludes what it is" (HICKEY-MOODY, p. 92). In addition, the project more broadly works via a method of creating affective assemblages of research contexts: sounds, aesthetic economies of research sites, the indirect discourses through which research subjects speak, constitute simple ways in which the affects of our everyday life can inform the research. Finally, in this instance, by choosing to explore popular genre movies, the research draws upon a long history of scholarly writing in Film Studies which considers how audiences can productively engage with mainstream forms of entertainment - irrespective of artistic worth on the one hand, or suspicions regarding commercial connotations on the other - in ways which reveal both the agency of such audiences and the sophisticated complexity of cultural dynamics (e.g. DYER and VINCENDEAU, 1990; ELEFTHERIOTIS, 2001; DENNISON and SHAW, 2004).

Related to curriculum studies theories, the dimensions of the 'popular' could be connected to the deterritorialization of the curricular field into everyday life studies, underlining the hybridity of curricular policies and practices. Everyday life research is aligned with cultural 
studies, emphasizing language and the philosophy of differences, as marked by discourses of postmodernity. Culture enables the curricular field to keep its pragmatic commitment, as a force for change and criticism (AMORIM, 2011).

The arguments we will present in this paper reflect on a few procedures between cultural policy, multiculturalism, the very primacy of images and culture, all typical of cultural studies, which establish "culture" as hegemonic in curriculum studies in Brazil. Concepts like hybridity, the space of the in-between, trace and borders denote this state of affairs. How can we open them to other meanings?

\section{White Middle Class Suburban Comedy: representation and difference}

A brief plot synopsis will assist in uncovering what is at stake in a Deleuzian reading of how these films provide Brazilian audiences with a way of reimagining identity. Se Eu Fosse Você and Se Eu Fosse Você 2 are Globo Filmes coproductions, produced and directed by Daniel Filho and starring two prominent Globo Television actors, Ramos and Pires. In Se Eu Fosse Você Ramos plays Claudio, an advertising executive approaching his fiftieth birthday, who lives in a wealthy suburb of Rio de Janeiro with his wife, Helena (Pires). They have been married for over fifteen years, and have a teenage daughter, Bia (Lara Rodrigues). Due to a humorous generic plot device typical of the comedy (an aligning of the planets of Venus and Mars with Earth), Claudio and Helena are magically transported into each other's bodies one fateful night. They are forced to live each other's daily lives, the comedy effect this gender swap produces being typical of any number of gender (not to mention age) switch, comedies. The film resolves with a happy ending, with both husband and wife more aware of the difficulties of each other's respective lives: Claudio's as a self-employed publicity executive under pressure at work and Helena's as a suburban mother with responsibilities to her home, family and the children's choir she conducts.

Se Eu Fosse Você 2 for its part is a remake which rehashes the same territory, this time with the two characters involved in divorce proceedings. As before the resolution sees a happy reunion of the couple, coinciding on this occasion with the wedding of Bia (now played by Isabelle Drummond). In the main the milieu which Claudio and Helena inhabit is a luxurious world of suburban houses with private swimming pools, new cars, fashionable wardrobes, private schools and hi-tech offices. The normative status of this all-white world is emphasised most clearly in Se Eu Fosse Você by the recurring appearance of the household maid, Cida (Maria Gladys), who is clearly intended to function as an "excessive", uncomprehending, counterpoint to the middle class family at the centre of the comedy-drama.

The emergence of these extremely popular mainstream comedies is a consequence of recent transformations of the Brazilian film industry since the 1980s. A certain type of popular cinema, including the comedies under discussion here, can be seen to have emerged in response to what Stephanie Dennison and Lisa Shaw indicate in Popular Cinema in Brazil (2004) was a need, felt towards the start of the 2000 s, for commercial viability in the industry. This led the critics of national cinema and younger Brazilian producers into debate over how best to conciliate artistic originality, and its integrity, with commercial viability. As Dennison and Shaw note, whilst some producers returned to the cinematic styles of the past, others resorted to the continuous success of national TV shows, as well as to contemporary music, to create films starring popular artists 
from these industries. It is to a group of films partially produced in association with television channels (Globo Network remains the dominant force in Brazilian television as cited by Xavier, 2003) that Se Eu Fosse Você and Se Eu Fosse Você 2 belong. Yet, whilst such films, typically as much produced for television as for theatrical distribution, are prime candidates for critical discussions of the 'dumbing down' of Brazilian culture under the influence of Globo Filmes, a Deleuzian approach suggests that they may also offer more subversive pleasures than seem evident on first viewing (Shaw and Dennison, 2007).

Although it is something of a commonplace in academic writing on many national cinemas to consider films about families as allegories for the nation, even so, in contrast to the disintegrating families and the search for a stable home of some recent Brazilian films (Central do Brasil, for example), the temporarily destabilised family at the heart of the Se Eu Fosse Você movies creates an oscillation of both performed gender and familial roles (the most superficial inversion that propels the narrative) and also the nationally defining image of the middle class family. The most apparent oscillation takes place at the level of the narrative, with Claudio's performing of the role of wife, mother and school choral mistress whilst occupying Helena's body, and Helena's of husband, father and businessman whilst inside Claudio's. In this way a deterritorializing of each respective gendered sphere is clearly intended, for example in Se Eu Fosse Você with Helena (as Claudio) offering an alternative to the casual misogyny and exploitation of women in the advertising industry (and rejuvenating Claudio's failing business in the process), and Claudio (as Helena) successfully adding a modern dance routine to his wife's choir's performance of Beethoven, using his professional eye for an appealing concept.
Yet furthermore, and of crucial importance for this piece, beyond this rather obvious expose of the types of normative performance associated with bourgeois gender roles and their normative spheres, the previous fictional roles performed by the two lead actors, in the various telenovelas for which they are famous in Brazil, construct a virtual multiplicity of roles existing within each character - by virtue of the associations carried by their star personas. This illustrates the more subversive capacity these films make available to audiences familiar with these past roles, to identify with a variety of regional, ethnic and social class identities which appear to inhabit the already "body-snatched" middle class couple.

In this way the family/nation is destabilised through a virtual invasion of character akin to that which was so humorously portrayed in the US independent film Being John Malkovich (1999) as the inhabitation of the body of a movie star by a group of ordinary people looking for a second chance at life. In this instance, however, the viewing experience (as opposed to the film narrative) is most easily understood as a form of "home invasion", in which the normative white, middle aged, middle class, suburbanite, married couple have their bodies taken over by a multitude of virtual Brazilian characters of different regions, classes and ethnicities. Their collective pasts create a stuttering of the normative position afforded to the middle class family that is otherwise the focus of the film's narrative, a stammering of this key icon of national identity creation. The film asks us to consider: who is the truthful person? Claudio, Helen, a hybrid of the two, or even a multiplicity?

\section{Fabulation and Powers of the False}

It might initially seem rather eccentric to consider the workings of the powers of the false in 
Se Eu Fosse Você and Se Eu Fosse Você 2. These are conventional movement-image films, whilst the powers of the false are typically associated with the crystalline narration of time-images. If we follow Deleuze's argument then it is the organic narration of the movement-image, which 'consists of the development of sensory-motor schemata as a result of which characters react to situations, or act in such a way as to disclose the situation' and which is, accordingly, 'a truthful narration, in the sense that it claims to be true, even in fiction' (p. 123), that most aptly describes the narratives of Se Eu Fosse Você and Se Eu Fosse Você 2. They are a long way from the potentially falsifying, crystalline narration of the time-image. This type of falsification, after all, is not based on simple binary inversions, but upon a metaphysical consideration of a labyrinthine model of time which Deleuze extracts from the writings of Jorge Luis Borges and grafts onto Henri Bergson's model of the virtual cone of time. Even so, the idea of the powers of the false does share some common ground with the more performative aspects of the two films. This particular theoretical assemblage (Bergson, Borges and Nietzsche via Deleuze) enables a potentially falsifying reconsideration of the past in the present (with the implication of a repetition of identity in difference in the future) that has clear parallels with the notion of performative identity found in the writings of authors like Judith Butler (see MARTIN-JONES, 2006). Put simply, following Deleuze's line of reasoning, if a person is able to reimagine their past, this action has the potential to realign the virtual past such that they are able to become a different person in the future.

Deleuze (1989) expands upon the political impact of this kind of falsifying narrative when discussing the potential it has for the invention or creation of a people who are currently missing, a 'people to come' (p. 208) in works of 'modern political cinema' (p. 209) (often now referred to as works of 'minor cinema' (SUTTON and MARTIN-JONES, 2008)). Here again it is a question of finding or inventing a new past that will be informing of the future, for example in neo- or postcolonial(Ji-Hyun, 2015), contexts. Yet these ideas, which in Deleuze's work are formulated in relation to politically committed works of cinema that evidence such temporal characteristics of the time-image, are not easily transposed onto such mainstream movement-image comedies as Se Eu Fosse Você and Se Eu Fosse Você 2.

Even so, we would argue that the actions of the television stars in these films crystalise a cinematic actual present with a televisual virtual past, uniting them in an interval or viewing event within which new possibilities can be imagined for Brazilian identity. This is a type of fabulation, or rather an opportunity for an audience to engage in a fantasy of such. The context of fabulations created by both comedies help us to understand Deleuze's thesis about the concept of truth entering into crisis when it confronts the form of time: the form of the true then gives way to the powers of the false.

For Daniel W. Smith (2013), the first dimension of this Deleuzian concept of the power of false is related to distinction between the true and the real; the most important is the distinction between the real and the imaginary (or between essence and appearance). "The false is not the imaginary; it is rather the confusion of the imaginary with the real (or of the apparent with the essential)" (p. 384). When does the false take on a power of its own? - argues Daniel Smith (2013). "If time puts the concept of truth in crisis, it does so not at the level of its content ('truth changes with time'), but rather at the level of its form: the form of time takes the place of the form of the true (the universal and the eternal)" (p. 385). The crisis of Brazilian identities, but moreover, the crisis of gen- 
der, ethnic and class differences that must be sustained in the expression of cultural bodies and standard characters.

The powers of the false dialogue with the power of judgment about the utopian limits of the middle class and its cultural marks as a 'representative spectrum or diagram' for Brazilian people. But, what we are touching upon through the film analysis is that the "power of the false is a power of metamorphosis, that is, it is a power of creation" (p. 386). The creation of new forms of identification. At the same time, the movies are not different from the telenovela or other forms of popular fiction in terms of exploring the boundaries between reality and fantasy, the personal-intimate and the social-public, and convention and transgression. That is, the movies required the telenovela, the series and other national and foreign forms of television drama in order to assume the role of narrating Brazil's story anew (BRENNAN, 2012).

According to Niall P Brennan (2015), as interpreters, Brazilian television critics play a key role in interrogating the educational value of the mini-series that are transversally associated to a cinema movie, such as the movie Se eu fosse você. "Critics allow us to see that depicting historical or contemporary Brazilian experience requires a balance between drama and meaningfulness, and that to privilege instruction over the meaning of national experience can result in the loss of the mini-series' narrative forcefulnes" (BRENNAN, 2015, p. 699).

In other cases, the Brazilian mini-series and popular cinema offers stories through which it becomes possible to see subjective resistance to larger political, class, family, and moral frameworks. Following Brennan (2015), then: "We must therefore question whether such representations adequately reflect Brazilian experience, or serve as a device for Brazilian television to maintain its hold over the imagination of the public" (BRENNAN, 2015, p. 700). A
Deleuzian interpretation of these mainstream comedies indicates that the fabulation of the public, orchestrated by television and soap operas, works to produce a new sense of and for people to come. When the form of time is put into the concept, the falsifier [le faussaire] takes the place of the truthful person-and the falsifier is more or less equivalent to the artist, the creator. The roles of Tony Ramos and Gloria Pires are as artists who operate in the middle of forces and power of representation as a falsifiers. "The falsifier is not a liar, since the liar is localisable (the liar 'owns' his lies), whereas the falsifier is non-localisable: the power of the false exists only under the form of a series of powers" (SMITH, 2013, p. 386). Believing in them, the public can reorganize the pre-established places for Brazilian identities based on cultural markers of identification, even if working with stereotypes and clichés.

Rather than simply dismissing the falsifiers as an aberration from the real, the public works through the movies with the fabulation as a positive power of creation. A genuinely creative process, with the 'powers of the false': 'a way of falsifying orthodox truths and fashioning new truths, with the ethical aim of fostering a people to come' Deleuze's commitment to the power of fabulation underscores his overturning of Platonism-to free the copy and its simulacrum from a compromised 'real'-and in the footsteps of Nietzsche, to repudiate representations of the 'true.' (SCANNELL, 2014).

Instead of thinking that what is being transformed are differences, as if there were several differences that are repeated to assume a new identity, what has to be changed is the 'same', the idea of the unit. The idea of universality is what needs to be changed, and immanence is the possibility of extending differentiation to (the ungrounding of) universality. Differences will return in every eternal life that is lived to change that 'same' eternal that we would all 
identify with. This is the proposal of the idea of the eternal return. This is why Deleuze always insists that only the difference, not the similar or the same, returns. Although the eternal return is the eternal of that we have lived, it is always a different return, it is not the return of the same; otherwise it would be the return of an enlightened idea or of a critical consciousness.

As the preceding analysis demonstrates, Se Eu Fosse Você and Se Eu Fosse Você 2 provide an opportunity for Brazilian audiences to experience the powers of the false through character identification, and as such offer new possibilities for national identity creation. This process, or event, destabilizes the form of the true (the normative Brazilian family) invading its suburban home with a range of not necessarily true virtual (in this case, televisual) pasts. In so doing, along with the stuttering of the performance of established gender roles that we expect of a gender swap comedy, so too is the ethnic primacy of the white, middle class family in Brazil forced to stammer through encounters with its regional, social class, ethnic and sexual others.

\section{Conclusion: the fabulation of identity into difference}

Studying the narrative and aesthetics of these artistic productions, how they reconstruct the world, and understanding their implications for people, these are the major points of Amorim's research on the curriculum, tracing relationships between subjects, cultures and the role of difference. The relationship between culture and language is disregarded in favor of discourse as a metanarrative of the cultural curriculum. Besides the persistence of the centrality of a unified identity and the illusion of the substance of the subject, this means that "discourse and language" become a new, if disguised, form of structuralism.
According to Reynolds (2006), in curriculum studies there have also been and continues to be discussion centering on the nature of the field. The complicated conversation that is the curriculum requires interdisciplinarity intellectuality, erudition and self-reflexivity. In the case of cultural curriculum studies this author points that there are

passages or lines of flight among the work done in both cultural studies and curriculum studies, which could encourage work in both to cross the borders of each. Cultural studies can study issues in curriculum and areas of curriculum studies could concentrate on the cultural issues that are the focus of cultural studies, since the curriculum that matters to children and the rest of us is the culture in which we dwell (REYNOLDS, 2006, p. 47)

The Deleuzean concepts we work with in this paper counter what Wallin (2010) refers to as the 'tyranny of overdetermination' those rigid, predetermined and striated lines of thought that leave the state of things completely intact. Analyzing both films, we try to operate with the tensions of the fictionalized real: the registration and invention of space and time. We create with language a fabulatory legend of a world that is open to the forces of time. When analyzing cinematic productions, it is a matter of catching a glimpse of the overflowing relationship between audiovisual pedagogies and language when they are in the company of signs. For these are objects of a temporal learning, implying heterogeneity as relationship. In other words, following the suggestion of Orlandi (2011), we must think of these relationships as critical to every or any standardization of bodies and souls, and we should be able to extract difference - crucial to any process of creation and introduction of something new. As Parente explains:

The image thought outside of us. Then it began to think about us, commanded by language. Today, with the image industrialization, the image 
thinks for us. We had made of the image, our home, now it makes us its address and an address where the guest, so long ago, has become an unwelcome guest $(2004$, p. 29).

In explaining the image using language, education takes over the representation, and bets on the impotence of thinking about the difference in itself, and captures it "by the recognition, distribution, reproduction, resemblance, to the extent that they alienate the RE prefix in its simple generalities" (DELEUZE, 2006, p. 201).

There are also lines of escape that enter a path that think the image without a practical bias - uncover, criticize, analyze, code and other verbs that put the subject (researcher, teacher, coordinator, director, worker of education) in a situation of agency. If a thousand emotional

\section{References}

AMORIM, Antonio Carlos. Fotografia, som e cinema como afetos e perceptos no conhecimento da escola. Teias, Rio de Janeiro, v. 8, p. 1-17, 2007. Disponível em: <http://www.e-publicacoes.uerj.br/index.php/ revistateias/article/view/23998>. Acesso em: 09 ago. 2017.

AMORIM, Antonio Carlos. Non-figurative narratives or life without subjects. In: SCHERTO, Gill. (Ed.). Exploring selfhood: finding ourselves, finding our stories in life narratives. Brighton: University of Brighton; Guerand Hermès Foundation, 2009a. p. 167-190.

AMORIM, Antonio Carlos. The day after the end, becoming post-. Biopolitics, Ethics, and Subjectivation: questions on modernity. International conference \& summer university, Hsin Chu, Publisher of Graduated Inst. for Social Research and Culture Studies of National Chiao Tung University, v. 4, p. 87103, 2009b.

AMORIM, Antonio Carlos Rodrigues de. Curriculum DisFiguration. In: PINAR, William. (Ed.). Curriculum studies in Brazil. Intellectual histories, present circumstances. New York: Palgrave Macmillan, 2011. p. 55-70.

AHN, Ji-Hyun. Desiring biracial whites: cultur- factors can affect the most trivial perception, it is because the object given there is 'flesh and blood', in a perceptual structure constant and strong apparently 'based' in a non-objective spatial texture, imaginative. This is what makes it precarious, ready to be released of its context (as shown by hallucinations, and disturbances of perception, according to Gil (2005).

$A$ radical displacement of reality could be represented as true. It can be told, understood, and not located. Language translation instituted as foreign - that is, a visuality without images, like a photograph transferred through writing, a "non-eye" image. Pure fabulation that is associated with an idea of perception never entirely objective, but always threatened by a destabilizing movement.

al consumption of white mixed-race celebrities in South Korean popular media. Media, Culture \& Society, v. 37, n. 6, p. 937-947, 2015. Disponivel em: <http://journals.sagepub.com/doi/ full/10.1177/0163443715593050>. Acesso em: 10 jul. 2017.

BRENNAN, Niall P. The brazilian television mini-series: representing the culture, values and identity of a nation. 2012. 297 f. Thesis (Ph.D in Philosophy) Department of Media and Communications, London School of Economics and Political Science, London, 2012.

BRENNAN, Niall P. Authority, resistance, and representing national values in the Brazilian television mini-series. Media, Culture \& Society, v. 37, n. 5, p. 686-702, 2015. Disponivel em: <http://journals.sagepub.com/doi/full/10.1177/0163443715577241>. Acesso em: 09 jul. 2017.

DELEUZE, Gilles. Diferença e repetição. Tradução de Luiz Orlandi e Roberto Machado. 2. ed. Rio de Janeiro: Graal. 2006.

DELEUZE, Gilles. Cinema 2: the time image. Translated by Hugh Tomlinson and Robert Galeta. Minneap- 
olis: Minnesota University Press, 1989.

DENNISON, Stephanie; SHAW, Lisa. Popular cinema in Brazil. Manchester: Manchester University Press, 2004.

DYER, Richard; VINCENDEAU, Ginette. (Eds.). Popular european cinema. London: Routledge, 1992.

ELEFTHERIOTIS, Dimitris. Popular cinemas of Europe. London: Continuum, 2001.

GIL, José. A imagem-nua e as pequenas percepções. Estética e metafenomenologia. 2. ed. Lisboa: Relógio D’Água, 2005.

HICKEY-MOODY, Anna. Affect as a method: feelings, aesthetics and affective pedagogy. In: COLEMAN, Rebecca Coleman; RINGROSE, Jessica. (Eds.). Deleuze and research methodologies. Edinburgh: Edinburgh University Press, 2013. p. 79-95.

JAGODZINSKI, Jan. On cinema as micropolitical pedagogy: is there an elephant in the classroom? In: CARLIN, Matthew; WALLIN, Jason. Deleuze \& Guattari, politics and education: for a people-yet-to-come. New York: Bloomsbury Academic, 2014. p. 15-48.

JANKIE, Dudu. When post-colonial critique meets curriculum history. In: BAKER, Bernadette. (Ed.). New curriculum history. Roterdam; Boston; Taipei: Sense Publishers, 2009.

LAZZARATO, Maurizio. Machines to crystallize time: Bergson. Theory, Culture \& Society, v. 24, n. 6, p. 93122, 2007.

LISPECTOR, Clarice. A imitação da rosa. In: Laços de família. Rio de Janeiro: Rocco, 1998. p. 35-58. MARTIN-JONES, David. Deleuze, cinema and national identity. Edinburgh: Edinburgh University Press, 2006.

NAGIB, Lúcia. Brazil on screen. London: I. B. Tauris, 2007.

ORLANDI, Luiz Benedito Lacerda. Deleuze entre o caos e o pensamento. In: AMORIM, A. C. R.; OLIVEIRA JR, W. M. Conexões Deleuze e imagem e pensamento e ... Petrópolis, RJ: DP et Alii, 2011. p. 145-154.

PARENTE, André. (Ed.). Imagem-máquina. A era das tecnologias do virtual. São Paulo: Editora 34, 2004.

PINAR, William. (Ed.). Curriculum studies in Brazil. Intellectual histories, present circumstances. New York: Palgrave Macmillan, 2011.

REYNOLDS, William M. Cultural curriculum studies, multiplicity, and cinematic-machines. Journal of Curriculum Theorizing, v. 22, n. 2, p. 41-53, 2006.

SCANNELL, John. The '419 Scam': an unacceptable 'power of the false'? PORTAL Journal of Multidisciplinary International Studies, v. 11, n. 2, p. 1-16, jul. 2014. Disponivel em: <http://epress.lib. uts.edu.au/journals/index.php/portal/article/ view/3220/4579>. Acesso em: 09 jul. 2017.

SEVERINO, Tiago Nunes. O seriado brasileiro como estratégia para conquistar o novo público dos canais pagos. Temática, ano XI, n. 1, p. 52-74, jan. 2015. Disponivel em: <http://periodicos.ufpb.br/index. $\mathrm{php} /$ tematica/article/view/22680/12545>. Acesso em: 02 ago. 2017.

SMITH, Daniel W. Temporality and truth. Deleuze Studies, v. 7, n. 3, p. 377-389, jul. 2013.

SPEGLICH, Erica. Duração: entre imagens do Programa Biota/Fapesp. 2009. 129 f. Tese (Doutorado em Educação) - Programa de Pós-Graduação em Educação, Universidade Estadual de Campinas, Campinas, 2009.

SUTTON, Damian Sutton; MARTIN-JONES, David. Deleuze reframed. London: I. B. Tauris, 2008.

WALLIN, J. A. Deleuzian approach to curriculum: essays on a pedagogical life. New York: Palgrave McMillan, 2011.

WUNDER, Alik et al. Imagens que acontecem nos deslocamentos em/de pesquisas. In: SIMPÓSIO INTERNACIONAL EM “EDUCAÇÃO E FILOSOFIA”, 1., 2006, Marília. Anais... Marília, SP: FFC/Unesp, 2006. p. 1-16.

XAVIER, Ismail. Brazilian cinema in the 1990s. In: NAGIB, Lúcia. (Ed.). The new brazilian cinema. London: I. B. Tauris, 2003. p. 39-64.

Recebido em: 10.08.2017 Aprovado em: 25.10.2017 
Antonio Carlos Rodrigues de Amorim - Professor in the Faculty of Education at the University of Campinas, Brazil, and a researcher in its Laboratory of Audiovisual Studies. He is a scholarship holder for productivity in research from the National Advisory for Scientific and Technological Development, specialized on visual culture studies and education. e-mail: acamorim@unicamp.br

Faculdade de Educação da Unicamp

Av. Bertrand Russell, 801 - Cidade Universitária "Zeferino Vaz" -Campinas - SP - Brasil

CEP 13083-865. Telefone: + 551935215647

David Martin-Jones - Professor of Film Studies, University of Glasgow. His research engages with what it means to study a world of cinemas. He is the author of several books, including Deleuze and World Cinemas (2011) (shortlisted for the BAFTSS Annual Book Award), has published in numerous journals (including Cinema Journal, Screen and Third Text), and co-edits the online resource deleuzecinema.com and the Bloomsbury monograph series Thinking Cinema. e-mail: David.Martin-Jones@glasgow.ac.uk

University of Glasgow

Gilmorehill Halls, 9 University Avenue. Glasgow, Scotland, UK

Telefone: +4401413303481 